\section{Amino Acid Components in Fossil Tortoiseshell from the Oligocene of the Isle of Wight}

Fossil bones and teeth from Palaeozoic, Mesozoic and Tertiary rocks have yielded amino acid analyses which indicate the survival of collagenous material over hundreds of millions of years ${ }^{1}$. In contrast, fossil keratinous tissues have until now only been recorded in such Pleistocene animals as the South American giant ground sloth and the woolly mammoth ${ }^{2}$. We are not aware of any earlier records. Ostrom ${ }^{3}$ in his account of the Dutch Archaeopteryx noted that "the actual horny claws are preserved", but he has since written that he "did not claim that the original keratin or horny tissucs were preserved". $\mathrm{He}$ was "quite confident that the original organic material
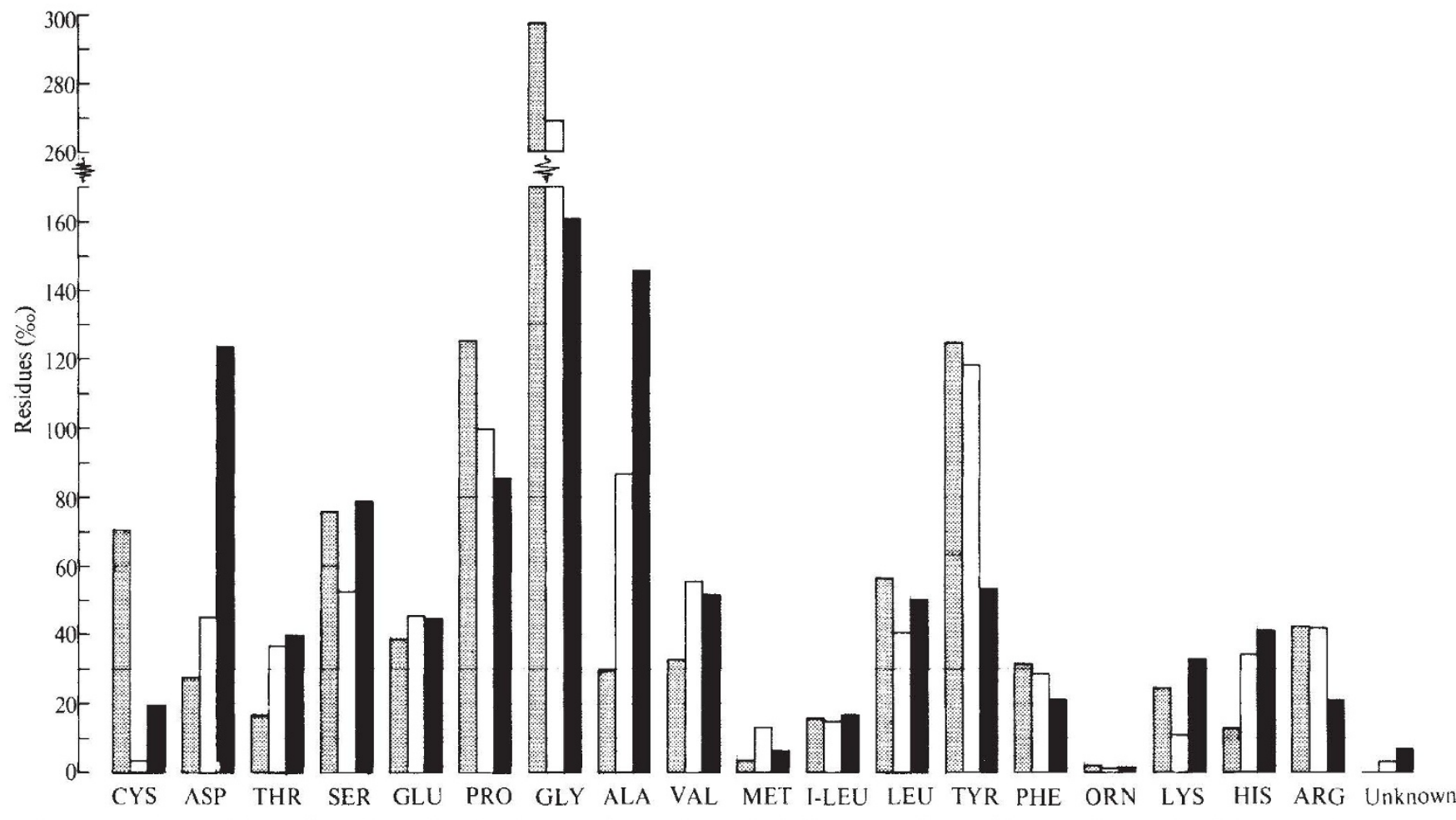

Fig. 1 Analyses of the amino acid residues in three specimens of tortoiseshell, expressed as residues per thousand residues. $\square$, Pelusios sp.; 㳑, Chelonia mydas. has been completely replaced by calcite" (private communication).

During an excursion to the Isle of Wight, a fossil was found on the beach to the east of Whitecliff Bay, on the flats immediately west of Bembridge. The specimen measured approximately $4 \times 1.5 \mathrm{~cm}$ and was translucent. It was identified as fossil tortoiseshell by one of us, although such material was unknown as fossil. Unfortunately it was not found in situ, but was mixed with bivalves belonging to the genus Corbicula, derived from the green marls of the Bembridge Marls ${ }^{4}$. The preservation in this deposit is somewhat unusual, in that even the colour banding of the bivalves still survives, and so it is the sort of deposit in which a material such as keratin might be expected to be preserved.

Analyses on various keratins have been restricted to hair, horn, nails, feathers and baleen ${ }^{5}$, and to date we have been unable to locate any accounts of the amino acid composition of tortoiseshell. Specimens of the tortoiseshell of two living genera, the marine Chelonia and the freshwater Pelusios, were analysed together with the fossil find, tentatively identified as amino acids present in the hydrolysates of the specimens were made by means of a Technicon automatic amino acid analyser. The results obtained are given in Fig. 1. Emys, the marsh-turtle. The separation and assay of the
The compositional profiles seem to confirm the original identification of the fossil specimen as tortoiseshell. Most of the amino acids are comparable in relative amounts with those recovered from the living material. The main exceptions are the increased proportions of aspartic acid and alanine and the reduction in glycine and tyrosine. These contrast with results from hair analyses, but can be matched with keratins derived from other tissues.

Although it is premature to draw any firm conclusions from these analyses, the differences between tortoiseshell and hair or wool are compatible with those between baleen and wool and hair. Fincham et al. ${ }^{6}$ suggested that the differences were a measure of the degree of calcification of the keratin, the proportion of proline increasing with mineralization. This indicates that tortoiseshell is fairly well calcified, which must have been a factor in its preservation. years, given suitable conditions of burial, could lead to further discoveries, enabling more palaeobiochemical analyses to be undertaken.

We thank Mr W. Martindale for the fossil specimen, Dr R. Moody of the Kingston Polytechnic for the living specimens and the Nuffield Foundation for a grant-in-aid.

Department of Biological Sciences,

L. B. Halstead

University of Ife, Ile-Afe, Nigeria,

and Royal Dental School of London, London WC2

\section{LILIANA WOOD}

Department of Biochemistry,

Royal Dental School of London, London WC2

Received December 4, 1972; revised April 25, 1973.

${ }^{1}$ Armstrong, W. G., and Halstead Tarlo, L. B., Nature, 210, 481 (1966).

2 Gillespie, J. M., Science, 170, 1100 (1970).

${ }^{3}$ Ostrom, J. H., Science, 170, 538 (1970).

${ }^{4}$ Chatwin, C. P., The Hampshire Basin and Adjoining Areas, third ed. (HMSO, 1960).

$s$ Pautard, F. G. E., Nature, 199, 531 (1963).

${ }^{6}$ Fincham, A. G., Graham, G. N., and Pautard, F. G. E., in Tooth Enamel (edit. by Stock, M. V., and Fearnhead, R. W.), 117 (Wright, Bristol, 1964). 